\title{
Political Rhetoric in China and in Imperial Rome: the Persuader, the Ruler, the Audience
}

De la rhétorique politique en Chine et dans la Rome impériale : l'orateur, le souverain, et le public

\section{Alexander Yakobson}

\section{OpenEdition}

\section{Journals}

Electronic version

URL: http://journals.openedition.org/extremeorient/263

DOI: 10.4000/extremeorient.263

ISSN: 2108-7105

Publisher

Presses universitaires de Vincennes

Printed version

Date of publication: 1 November 2012

Number of pages: 195-204

ISBN: 978-2-84292-352-5

ISSN: 0754-5010

\section{Electronic reference}

Alexander Yakobson, « Political Rhetoric in China and in Imperial Rome: the Persuader, the Ruler, the Audience », Extrême-Orient Extrême-Occident [Online], 34 | 2012, Online since 01 November 2015, connection on 24 April 2019. URL : http://journals.openedition.org/extremeorient/263 ; DOI : 10.4000/ extremeorient.263 


\title{
Political Rhetoric in China and in Imperial Rome: the Persuader, the Ruler, the Audience
}

\author{
Alexander Yakobson
}

The most fundamental difference between political rhetoric in traditional China and in the Greco-Roman world - and specifically in Rome, with which I will deal here-is, as is rightly stressed by some of the contributors to this splendid volume, that in China political rhetoric is invariably addressed by a "persuader" to a single man-the autocratic ruler, and not to the public or to collective civic bodies. In Romain Graziani's words, "This canonical political pattern must be understood within the broader context of the overarching paradigm of monarchism in Chinese political culture. The Chinese persuader is not strictly speaking a 'rhētōr', a public speaker defined by his command of the civic art of persuading"; "rhetoric in Chinese politics was never concerned with public address. By contrast, in ancient Rome, political rhetoric was focused on the manipulation of public opinion. A rhetor addressed a large audience," that could number thousands when he addressed the people or hundreds when he spoke in the Senate.

Roman Republican rhetoric is thus difficult to compare with Chinese rhetoric, either before or during the unified Empire. Under the Emperors, however, Rome came to be governed by an autocratic ruler-something that had been always considered an anathema under the Republic. At first, under Augustus, there was some official reluctance to acknowledge the autocratic nature of the regime; but already under his successor Tiberius (not to speak of the third in line, Gaius Caligula), there could no longer be any ambiguity concerning the absolute power of the Emperor. The collective civic bodies of the old Republic were not abolished, but became fully subservient to the ruler's will. The popular assemblies still had some, strictly limited, role under Augustus, but became purely formal occasions thereafter, till they disappeared altogether in the turmoil of the third-century civil wars. The Senate, too, was eventually destined, by the Late Empire, to be reduced to a forum for enthusiastic acclamations upon the receipt of Imperial decisions. But this development, although in accordance 
with the true spirit of the Imperial regime, was slow. For a long time after the establishment of the Emperors' rule - what the Romans called the principate - the Senate was still a body of considerable importance as a forum where political questions - still, officially, the public affairs of the Roman peoplewere discussed. Under "good" Emperors, senators enjoyed some degree of freedom in their deliberations - provided that the question at hand was not really vital to the regime. But there was never any question of the Emperor's will not prevailing whenever he insisted that it should prevail.

Since Augustus, major political decisions were made by the Emperor, after a consultation with a small group of "friends" and advisors; the Senate's subsequent approval, when needed, was a foregone conclusion. The Roman political decision-making process was thus, essentially, no different from the traditional Chinese one, however different the formalities: the sole ruler decided. While one could still earn considerable distinction and prestige by eloquent discourse in the Senate (or in the public law-courts), the only political persuasion that mattered was an advisor's ability to persuade the ruler.

For those in the educated elite of Roman society who were still influenced by Republican sentiments - even while recognizing that politically, there was no going back to the Republican system of government-any public rhetoric under the Emperors was but a pale shadow of the good old Republican art of oratory. Tacitus gives a voice to this sentiment in his Dialogus de Oratoribus (written perhaps $c a$ 101-102 CE, under the "good" Emperor Trajan, when such a theme could be tackled more or less safely). He enquires

how it is that whereas former ages were so prolific of great orators, men of genius and renown, our age is so forlorn and so destitute of the glory of eloquence that it scarce retains so much as the name of orator. That title we apply exclusively to the men of older time, while the good speakers of this day we call pleaders, advocates, counselors, anything rather than orators. (1) ${ }^{1}$

The answer is given by one of the speakers. It is - surely, at least half-ironicpraise of the Imperial autocracy and of the domestic peace brought by it; these leave no room for old-style oratory:

Again, what stimulus to genius and what fire to the orator was furnished by incessant popular assemblies, by the privilege of attacking the most influential men... The great and famous eloquence of old is the nursling of the license which fools called freedom; it is the companion of sedition, the stimulant of an unruly people, a stranger to obedience and subjection, a defiant, reckless, presumptuous thing which does not show itself in a well-governed state. What orator have we ever heard of at Sparta or

1. English translations will mostly follow the Loeb edition. 
at Crete? A very strict discipline and very strict laws prevailed, tradition says, in both those states. Nor do we know of the existence of eloquence among the Macedonians or Persians, or in any people content with a settled government... So too our own state, while it went astray and wore out its strength in factious strife and discord, with neither peace in the forum, unity in the Senate, order in the courts, respect for merit, or seemly behaviour in the magistrates [saw the art of oratory flourish; now, however, under the peaceful rule of the Emperors], what need there of long speeches in the Senate, when the best men are soon of one mind, or of endless harangues to the people, when political questions are decided not by an ignorant multitude, but by one man of pre-eminent wisdom? (40-42)

One man of pre-eminent wisdom (unus et sapientissimus) ruling the state-all my friends and colleagues from Chinese studies will surely feel comfortably at home hearing that. Still, two major differences remained between Chinese and Roman political rhetoric - both of them, obviously, remnants of the old civic culture that influenced all those involved, including the Emperors. The ruler himself practiced rhetoric in public - first and foremost before in the Senate, but occasionally also before the people; this rhetoric might, at least in style, be more "civic" than what can usually be expected from an absolute monarch. And the ruler's assistants and advisors, trying to persuade him, are repeatedly described in the sources as employing a type of rhetoric that is likewise influenced by what still remained of traditional-i.e., Republican-sentiments and conventions. Sometimes they address the ruler in the Senate, but from time to time the same conventions seem to apply to what is reported from consultations between the Emperor and a narrow circle of his trusted advisors. There, too, these advisors are sometimes described as employing a "senatorial" type of eloquence that brings to mind what Queen Victoria is said to have once remarked about her heartily disliked Prime Minister Gladstone: "He talks to me as if he were addressing a public meeting."

Admittedly, we do not have, for these consultations, anything like the official records of China, nor do we have the records of senatorial proceedings (though these were available to Tacitus and Suetonius). It is thus possible that some of the "civic" rhetorical features that appear in the sources that describe these consultations reflect, at least partly, the conventions and assumptions of Roman historians rather than what was actually said on those occasions. On the other hand, as we shall see, on the one occasion where we have both an account of an Imperial speech in the Senate by Tacitus and the actual record of what was said by the Emperor, the speech as delivered sounds even more "civic" that the historian's account.

As for Imperial eloquence, Tacitus, remarkably, reproaches Nero for using a speechwriter: the eulogy delivered by him at the public funeral of his adoptive 
father, the Emperor Claudius, had been written by his teacher and political advisor, Seneca. It was noted, says the historian, that

Nero was the first ruler to stand in need of borrowed eloquence. For the dictator Caesar had rivaled the greatest orators; and Augustus had the ready and fluent diction appropriate to a princeps (quae deceret principem). Tiberius was, in addition, a master of weighing words - powerful, moreover, in the expression of his views, or, if ambiguous, ambiguous by design. Even Gaius' troubled brain did not affect his power of speech; and, when Claudius had prepared his harangues, he did not lack elegance. (Annales, 13.3.3) ${ }^{2}$

Caesar, of course, was a Republican politician turned dictator who continued, as dictator, to use what had been an indispensable tool for him when he still had to compete with others for political influence - the orator's art. For Augustus, public eloquence was no longer, strictly speaking, a political necessity - still less so for his more openly absolutist successors. It was, however, a powerful cultural tradition to which these rulers felt themselves beholden. Their deference to this tradition signified that they still regarded themselves, in some significant sense, as elected officials (however all-powerful) of the Roman commonwealth; they had received - formally - their powers from the Senate and People of Rome, and accepted that some kind of interaction between them and the public at large, and especially with the Senate, was appropriate.

The Emperor Marcus Aurelius received, $c a 162 \mathrm{CE}$, this piece of advice on the importance of rhetoric to the ruler from his old teacher Fronto:

For it falls to a Caesar to carry by persuasion necessary measures in the Senate, to address the people on many important matters in public meetings, to correct the inequities of the law, to dispatch letters throughout the world... All these must assuredly be done by speech and writing. Will you therefore not cultivate an art which you see must be of great use to you so often and in matters of such great moment? (Ad M. Antoninum de eloquentia 1 [Naber: 139] 5.)

The evidence for Emperors addressing the people that is available to us suggests that this was in fact a rather less regular occasion than Fronto indicates (though sometimes this could still happen in the Late Empire, when even Imperial appearances before the Senate had become exceptional: when Constantius made his visit to Rome in 357 CE, he "addressed the nobility in the Senate-house and the populace from the tribunal" [Ammianus 16.10.13]). "The routine addresses

2. Fronto has a more pessimistic account of the earlier Emperors' capabilities as regards rhetoric, but public eloquence is for him, in this letter and elsewhere, indispensable for an Emperor - Ad Verum Imperatorem, 2.1 (Naber: 119), 6. 
to the people to which Fronto seems to be referring are not clearly attested.." ${ }^{3}$ It is of course possible that numerous events of this kind failed to find their way into the sources available to us. But it is also possible that Fronto was influenced by Rome's cultural and political traditions when presenting the Emperor as being in constant need of exercising the art of persuasion in public, before the Senate and (even) the people, as if he were still (merely) a Roman magistrate - not just learning rhetoric from Cicero's writings but acting in a manner reminiscent of Cicero as a Republican politician.

Certainly, Fronto's account gives a wholly exaggerated impression of the extent to which a Roman Emperor actually needed to persuade anyone in order to rule. It is, of course, not uncommon for autocratic rulers, in various cultures, to attach importance to winning the hearts and minds of their subjects - and especially of the elites. Rhetoric addressed (usually in writing) by a ruler to his subjects is by no means a uniquely Roman phenomenon. What is special about Imperial Rome is that the autocratic ruler might address his subjects (whether orally or in writing) in a way that implied that they were fellow-citizens rather than subjects. The Roman state was not really governed, in Marcus Aurelius' days, by the Emperor "carrying by persuasion necessary measures in the Senate," much less by "addressing the people on many important matters in public meetings," as Fronto puts it. Both he and his pupil, the Emperor, knew, of course, that this was a highly idealized and anachronistic picture of Roman government. The letter is itself a piece of rhetoric, both aiming to persuade the ruler and reflecting cultural conventions shared by both sides. It is quite remarkable that these conventions still carried weight in the second part of the second century $\mathrm{CE}$, long after any trace of a doubt as to the absolutist character of the Imperial rule, if it ever really existed, had disappeared. Absolute power may perhaps corrupt absolutely, or at least considerably (though Marcus Aurelius is hardly the most flagrant example of this rule), but this does not mean that an absolute ruler is not influenced by cultural conventions. This applies both to Rome and to China-much as the content of those conventions was different in each cases.

Under Augustus, the ruler's insistence on adhering to the tradition of direct contact between Roman magistrates and the people produced an incident that is wholly unthinkable in any proper monarchy, under any of Augustus' successors, as well as, one suspects, in Augustus' own later years. In 22 BCE, when the city of Rome was suffering from famine, there was public demand for Augustus

3. Fergus Millar (1977). The Emperor in the Roman World, 31 BC-AD 337. Ithaca, Cornell University Press: 203; but Millar refers to HA, Sev. Alex. 25.11, which may indicate that such events may have been more common than we usually assume, even after the Early Principate. 
to assume the office of dictator in order to tackle the problem with greater efficiency:

When the people did their best to force the dictatorship upon him, he knelt down, threw off his toga from his shoulder, and with bare breast begged them to desist. (Suetonius, Augustus, 52)

The most amazing part of this story is that there were still some people in Rome who appear to have thought that dictatorship would add something to Augustus' power. Unless the event was wholly staged (a suspicion that comes naturally to a cynical modern mind, but is perhaps misplaced in this case), this shows that at that point there was still some uncertainty (at any rate among the common people - the senators surely knew better) as to the true nature of Augustus' power. If there was any such misunderstanding, it did not continue beyond the first years of the principate.

As for the kind of rhetoric that might be addressed to the ruler by his advisors, this is how Tacitus describes a debate that took place in $48 \mathrm{CE}$ under Claudius, when a number of notables from Gallia Comata (the "long-haired," unRomanized part of Gaul conquered by Julius Caesar) who had already received Roman citizenship requested permission to start a senatorial career:

Comments on the subject were numerous and diverse; and in the Emperor's council (apud principem) the debate was conducted with animation on both sides: "Italy," it was asserted, "was not yet so moribund that she was unable to supply a Senate to her own capital. The time had been when a Roman-born Senate was enough for peoples [Latin and Italians allies] whose blood was akin to their own; nor was the old Republic [when this happened] anything to be ashamed of. Why, even today men quoted the patterns of virtue and of glory which, under the old system, the Roman character had given the world! Was it too little that Venetians and Insurbians [people from the Cisalpine Gaul beyond the Po enfranchised by Julius Caesar] had taken the Senate-house by storm, unless they brought in an army of aliens to give it the look of a captured town? What honours would be left to the relics of their nobility, or the poor senator who came from Latium? All would be submerged by those opulent persons whose grandfathers and great-grandfathers had smitten our armies by steel and the strong hand, and had besieged the deified Julius [Caesar] at Alesia. But these were recent events. [The anonymous speaker then refers to the legendary conquest of Rome by the Gauls in 390 BCE.] Leave them by all means to enjoy the title of citizens; but the insignia of senators, the glories of the magistrates - these they must not vulgarize."

Unconvinced by these and similar arguments, the Emperor not only stated his objections there and then, but, after convening the Senate, addressed it as follows: "In my own ancestors, the eldest of whom, Clausus, a Sabine by extraction, was made simultaneously a citizen and the head of a patrician house, I find encouragement 
to employ the same policy in my administration, by transferring hither all true excellence, let it be found where it will. [He proceeds with a long list of Republican and Imperial precedents for the extension of Roman citizenship throughout Italy.] Is it to be regretted that the Balbi crossed over from Spain and families equally distinguished from Narbonese Gaul? Their descendants remain; nor do they yield to us in love for this native land (amore in hanc patriam). What else proved fatal to Lacedaemon and to Athens, in spite of their power of arms, but their policy of holding the conquered aloof as alien-born? But the sagacity of our own founder Romulus was such that several times he fought and enfranchised a people in the course of the same day! [Other daring innovations are cited as proof that the Roman state was traditionally unafraid to innovate; the Gauls, he then says, were indeed once our enemies, but so were once all the long-enfranchised peoples of Italy.] Now that customs, culture and the ties of marriage have blended them [the Gauls from Gallia Comata] with ourselves, let them bring among us their gold and their riches instead of retaining them beyond the pale! All, Conscript Fathers, that is now believed supremely old has been new... Our innovation, too, will be parcel of the past, and what today we defend by precedents will rank among precedents."

The Emperor's speech was followed by a senatorial decree and the Aedui became the first to acquire senatorial rights in the capital: a concession to a long-standing treaty and to their position as the only Gallic community enjoying the title of brothers of the Roman people." (Annales, 11.23-24)

Both speeches, to and by the Emperor, as reported by Tacitus, are equally "public" in tone and argumentation. The advisors address the Emperor, in a sense, "as if they were addressing a public meeting," and the Emperor addresses the Senate as if it were a genuine decision-making body. The Emperor's advisors' glorification of "the old Republic" was, of course, in no way subversive - the Republic was already "ancient history" by that time, not a politically sensitive issue. Still, what is said about it here seems better suited to a speech before a public forum than in an autocrat's privy council; except that Roman Emperors themselves, who often shared-or pretended to share - the senatorial view of the world, might actually refer to "the old Republic" in a similar, theoreticallynostalgic way. ${ }^{4}$ These were, as educated Romans from higher orders knew, the good old days (at any rate before the Republic's last, turbulent decades), even though all reasonable people understood there was no going back to them, because, under "modern" conditions, that could only mean the renewal of civil wars.

Similarly, Tacitus relates the arguments put forward by Nero's advisors against his rash idea of doing way with indirect taxes "in consequence of repeated demands from the public": "The tax-collecting companies were set up by consuls

4. See Tacitus, Historiae, 1.16; cf. Annales, 4.9. 
and plebeian tribunes while the liberty of the Roman people was still in all its vigor" (Annales, 13.50). Again, this might be a Tacitean cliché rather than one actually used by Nero's advisors; on the other hand, Tacitus might perhaps be expected to portray the language of Nero's advisors as even more, rather than less, servile than it could be expected to sound.

Going back to Claudius' speech: exceptionally, we do have a record of what was actually said by the Emperor on this occasion: large parts of the speech were preserved on a bronze tablet found in Lyons. In it, Claudius "plays the senator" even more that in Tacitus' version, pretending to be unsure of his ability to convince his colleagues, such as they ostensibly were (Augustus had first established the rule that the name of the princeps was put first in the list of senators). He even "reprimands" himself, in the middle of the speech, for abusing their patience by straying away from the topic at hand:

I deplore the first thought of all men, which, I foresee, will stand in my path first and foremost, lest you shy away, as if from the introduction of some revolutionary innovation; rather, think instead how many changes have occurred in this state... from the very foundation of the city...

But, you may say, is an Italian senator not better than a provincial one for all that? When I come to deal with this part of my censorship, I shall then show you by my actions what I feel on this matter. But not even provincials should be excluded, if they can ornament the Senate House after all...

It is now time, Tiberius Caesar Germanicus, to reveal to the Conscript Fathers [the usual way to designate senators in a senatorial speech] where your speech is leading; for now you have come to the farthest borders of Gallia Narbonensis [mentioned in the previous passage]...

It was with some timidity, Conscript Fathers, that I left the boundaries of provinces known and familiar to you, but I must now plead the case of Gallia Comata most strenuously...5

Claudius' self-rebuke in the middle of his speech should perhaps be seen as reflecting his personal idiosyncrasies and his notoriously less-than-dignified manner (on occasion); this was hardly the proper way for a princeps to display his civility. ${ }^{6}$ But the whole posture of being the senators' (senior) colleague, ${ }^{7}$ in need of winning them over by his arguments, rather than being their master,

5. E. Mary Smallwood (1967). Documents Illustrating the Principates of Gaius, Claudius and Nero. Cambridge, Cambridge University Press: 369.

6. On the virtue of civilitas displayed by "good" Emperors see A. Wallace-Hadrill (1982). “Civilis princeps: Between Citizen and King." Journal of Roman Studies, no. 72: 32-48.

7. Cf. Suetonius, Tiberius, 29 for an example of "civic" speech addressed by an Emperor to a fellow-senator, in the House; "I crave your pardon, if in my capacity as a senator I use too free language in opposing you"; $c f$. Tacitus, Historiae, 2.91. 
was very much part the tradition, established by Augustus, of how an Emperor, ideally, should appear before the Senate. Of course, the result of the debate was never in any doubt: it was inevitable that the Emperor's speech would be followed by a senatorial decree accepting his proposal (though it cannot be ruled out that the precise terms of the decree, and the privileging of the Aedui, also reflected the senators' preferences expressed after the Emperor's speech). In fact we have, under Claudius, an actual record of an eloquent and almost touching attempt by the Emperor to galvanize the Senate into holding something approaching a genuine debate on an Imperial proposal:

If these proposals find favour with you, Conscript Fathers, signify immediately, simply and in accordance with your own opinion; if they do not find favour, devise alternative remedies, but do so here and now; or if you want, perhaps, to take time to consider the matter at a greater leisure, take it, provided that, wherever you are convened, you remember that you are to speak your own opinions. It ill becomes the dignity of this House, Conscript Fathers, that here just one consul designate should speak his opinion drawn verbatim from the motion of the consuls and that the rest should speak one word: [I] agree, and then, when they are disbanded: [we] debated. ${ }^{8}$

Ultimately, of course, the wish of some of the Emperors (at any rate when they were in a conciliatory mood) to benefit from a genuine senatorial debate, could not prevail over the fundamental logic of Imperial autocracy that militated against it. The Senate in Claudius' time had already made great strides, even compared with the Senate under Augustus, towards the Senate of the Late Empire that was no longer required even to rubber-stamp Imperial decisions by a formal vote, but rather had them read out before it and met them with repeated enthusiastic acclamations. ${ }^{9}$

Under the first Roman Emperor things were still very different. Suetonius, the biographer of the Caesars, addressing the early second-century (CE) Roman audience, clearly expects his readers (for all that they lived under "good" Emperors) to marvel at the degree of freedom that Roman senators under Augustus still enjoyed:

8. E. Mary Smallwood (1967). Documents Illustrating the Principates of Gaius, Claudius and Nero. Cambridge, Cambridge University Press: 367.

9. A good example is provided by the way the Senate "approved" the Codex Theodisianus in $438 \mathrm{CE}$ : an imperial degree proclaiming the publication of the Codex and its validity in both parts of the Empire was read out before the Senate in Rome and met with 43 different acclamations praising the Emperors (of the East and of the West), each repeated many times -829 acclamations in all, duly recorded-Codex Theodosianus, Gesta senatus Romani de Theodosiano publicando. 
As he was speaking in the Senate someone said to him: "I don't understand" and another - "I would contradict you if I had the opportunity." Several times when he was rushing from the Senate in anger at the excessive bickering of the disputants, some shouted after him "Senators ought to have the right of speaking their mind on public affairs." (Augustus, 54)

We also have, from Suetonius, an account of a senior senator actually succeeding in persuading Augustus to change his mind, on an important and sensitive subject, by his intervention in the course of a senatorial debate. The issue was precisely of conferring on the ruler of the title/name of Augustus, in January 27 BCE. The original idea, supported by the ruler himself, was to call him Romulus - as a second founder of the city. This name, however, had uncomfortable associations with royalty, and moreover according to one version of the events, Rome's first king was assassinated by senators. Eventually, the man history knows as Augustus was persuaded to change his mind and take up this name; remarkably, this appears to have happened in the course of a senatorial debate on this subject:

[The princeps received the name of Augustus on a motion of Plancus], who, when some expressed the opinion that he ought to be called Romulus as a second father of the city, carried the proposal that he should rather be named Augustus, on the grounds that this was not merely a new title but a more honourable one [because of its sacral associations] (Augustus, 7)

Suetonius does not explicitly say that the debate was in the Senate, but this seems to be clearly indicated by his use of technical senatorial terms (sententia, quibusdam censentibus). ${ }^{10}$ We would certainly have expected any vote in the Senate on a matter of such importance and delicacy to have been merely a ratification of a decision taken beforehand in a narrow circle of the ruler and his close associates. But if any such prior decision had been made before the Senate assembled, Plancus appears to have succeeded in persuading the princeps to change his mind - of course, the final decision of the Senate was in any case bound to follow his wishes - by a speech made in front of hundreds of senators. We see how the art of persuasion could be exercised, effectively, in a Rome that was already an autocratic state-for it was the sole ruler whose opinion was decisive, and needed to be influenced; and moreover, somewhat ironically, the important question of public policy at hand, debated in the Senate with relative openness and freedom, was which sacral title the ruler should receive. Nevertheless, in some significant respects the system still functioned not in a "normal" monarchical way, and this had important consequences in the field of political rhetoric.

10. Cf. Florus, 2.34 (tractatum etiam in senatu an...). 
The second Roman Emperor, Tiberius, still attended meetings of the Senate regularly during the first years of his reign. The inherent tension between the autocratic nature of the regime and still-surviving conventions of public debate on public affairs, in the Emperor's presence and sometimes with his active participation, created awkward situations. Transacting public business before the wide audience of members of the Roman elite inevitably imposed certain constraints on the Imperial autocracy. On the other hand, it was in the nature of the principate that the whole public aspect of government was used by the regime in order to enhance its legitimacy. A senator was not supposed to be a mere yes-man; he might well disagree with the Emperor-for example by suggesting, on even insisting, that even greater powers and honours should be bestowed on him. In the first days of Tiberius' reign (before he had even been officially confirmed as princeps-following an elaborate ritual of "refusal," that was only overcome after the senators persuaded him, with great difficulty, that the supreme interests of the state demanded that he should accept the Imperial power ${ }^{11}$ ), the following exchange took place between Tiberius and one of the senators:

Valerius Messalla suggested that an oath of allegiance to Tiberius should be renewed annually. To a query from Tiberius, whether that expression of opinion came at his dictation he answered (this was the one form of adulation still left) that he had spoken of his own accord, and, when public interests were in question, he would use no man's judgment but his own, even at the risk of giving offence. (Tacitus, Annales, 1.8)

Similarly, we have a case when the Emperor's refusal to accept charges of maiestas (lèse-majesté) that seemed to him trivial prompted a protest that was an act of base flattery disguised as a show of senatorial independence (perhaps more in the hope to ingratiating oneself with the ruler than in any genuine attempt to change his mind):

Lucius Ennius, a Roman knight, was accused of maiestas, for having converted a statue of the Emperor to the common use of silver plate; but the Caesar forbade the entry of the case for trial, though Ateius Capito protested openly, with a display of freedom (quai per libertatem); "The Senate," he said, "ought not to have wrested from it the right of decision, nor should so grave an offense pass without punishment. By all means let the Emperor be easy-tempered when it comes to a personal grievance, still he should not be generous in the case of wrongs to the commonwealth.” Tiberius understood this for what it was, rather than for what it purported to be, and persisted in his veto. (Tacitus, Annales, 3.70)

11. Tacitus, Annales, 1. 11-13; Suetonius, Tiberius, 24. 
But the opposite could also happen - a real show of independence disguised as servility and flattery, the result of which was to shame the Emperor into changing his mind:

[An accused was charged with] placing his own statue above those of the Caesars, while in another the head of Augustus had been struck off to make room for the portrait of Tiberius. ${ }^{12}$ This incensed the Emperor so much that, breaking through his taciturnity, he exclaimed that in this case he too would vote, openly and under oath - the object being to impose a similar obligation on the rest. There still lingered even then some traces of dying liberty. And so Cneius Piso asked, "In what order will you register your opinion, Caesar? If first, I shall know what to follow; if last of all, I fear that I may differ from you inadvertently." Tiberius was deeply moved, and with a meekness that showed how profoundly he rued his unwary outburst, he voted for the acquittal of the defendant on the counts of maiestas. (Tacitus, Annales, 1.74)

Piso's pseudo-servile question put into sharp relief the fact that Tiberius was coercing the Senate-something that he was unwilling to admit openly. We see - here and in general-the importance of the public nature of the proceeding, and of the senatorial audience. In the end, only one man will decide-if he insists on deciding; the Senate, in fact, was no longer a decision-making body but an audience-except for the increasingly minor matters that the Emperor left for it to decide on. ${ }^{13}$ But the sole ruler is keenly aware of the audience in front of which he acts, representing, as it does, the elite of Roman society; ${ }^{14}$ he is, to some extent, constrained, in exercising his autocratic power, by cultural conventions that he, avowedly, shares with it. Even the way the Emperor's close advisors sought to persuade him at confidential consultations, might, according to our sources, be influenced by these cultural conventions (though all we can be sure of is that there was a literary convention to describe those consultations in such a way).

Of course, all this applies to those Emperors who wished to be considered "civic." A tyrant like Gaius Caligula would play a very different game; ${ }^{15}$ and

12. Tiberius was evidently incensed because an act disrespectful to his deified father had been committed while honoring him.

13. Suetonius gives examples of senatorial decisions passed against Tiberius' express opinion (Tiberius, 21). The issues dealt with are trivial, and the phenomenon does not repeat itself after Tiberius' early years.

14. Cf. Tacitus, Annales, 2.38: Tiberius changes his mind (admittedly, on an issue of no political importance, relating to an impoverished senator's request for financial assistance) after "feeling the chill" in the Senate, following his initial refusal that was met with "silence and suppressed murmur."

15. This does not mean that Caligula did not practice public speaking: "As regards liberal studies, he gave little attention to literature but a great deal to oratory, and he was as 
Tiberius, in his later, more openly despotic years, removed himself not just from the Senate but from the city of Rome altogether. But even Caligula had a "good" period (from the senatorial point of view) at the beginning of his reign, and so did Nero - for a much longer period of time.

In the long run, the Senate, as a collective deliberative body, was destined to recede into insignificance, and Roman autocracy was destined to shed, progressively, the features that distinguished it from "normal" autocracies. When Fronto was writing his letter "de eloquentia" to Marcus Aurelius, ca 162 $\mathrm{CE}$, this process was already well under way. Fronto addresses the Emperor as "Lord" (domine, in the vocative), which, as we know from the correspondence of Pliny the Younger with Trajan, had by that time become the usual way to address the Emperor-something that had been emphatically rejected by both Augustus and Tiberius. But, as we have seen, the influence of the senatorial view of the world is still strong. Though they both knew better, Fronto still describes to the Emperor the nature of his office-admittedly, in a context that almost requires exaggerating the importance of rhetoric - in a way that presents him, still, as the first citizen of what is still a commonwealth, whose ability to lead the state is largely dependent on his ability to persuade the Senate-and even the people. Since this description reflects cultural conventions common to both men, we need not assume that there was any deliberate hypocrisy involved.

Roman Imperial political rhetoric, especially under the early Emperors, was thus different, in important ways, from the Chinese one, reflecting a very different political culture and tradition. It is not, however, obvious that the actual power of the Roman Emperor was, essentially, any less absolute than the power of his Chinese counterparts. Precisely because the power of a Roman Emperor was, at least formally, "civic" in its origin, and because he was, in some sense, the first citizen of the commonwealth, there was never any question of reducing him to a largely silent figurehead, too sacred to take active part in political deliberations. The culture of the educated elite influenced, of course, Chinese rulers too; though it accepted and celebrated their absolute power in principle, it seems to have succeeded, in some cases, to impose on its practical

ready of speech and eloquent as you please, especially if he had occasion to make a charge against anyone"-Suetonius, Gaius, 53; cf. Dio, 59.19.3-4: a senator accused by Caligula escapes death by pretending to be overwhelmed by the Emperor's eloquence: "repeating the accusation point by point, he praised it as if he were a mere listener and not himself on trial. When the opportunity was given him to speak, he... threw himself on the ground and lying there prostrate played the suppliant to his accuser, pretending to fear him more as an orator than as Emperor. Caligula, accordingly... was melted, believing that he had really overwhelmed Domitius by the eloquence of his speech." 
exercise restraints that were considerably more far-reaching than the ones in Imperial Rome.

It is true that when a Chinese ruler consulted his officials, this was not done in public, before an audience of hundreds. This is a significant difference. But is this quite the whole story? Did these proceedings necessarily lack a wider audience - in an indirect but potentially significant sense? If what was said behind closed doors could be expected to become known outside them, it stands to reason that this might influence what was said by the ruler's advisors, and even the behaviour of the ruler himself, to the extent that he cared about the relevant public opinion. This, both in China and in Rome, was the opinion of the educated ruling elite (though some remnants of the influence of a wider, popular, public opinion remained in Imperial Rome for a considerable period of time). One recalls, by way of analogy, the famous right to remonstrate possessed by certain Chinese high officials. The remonstrations were addressed, in writing, to the Emperor-but were they not sometimes written with an eye to a wider audience? And, because official records were kept in China much better, and on a much larger scale, than in Rome, there probably was another indirect audience that those who addressed the ruler, and possibly the ruler himself, must sometimes have had in mind: the educated history-reading elite of the future generations. The possible weight of such a consideration should not be underestimated. 